according to their capacity to profit by the education provided, and not according to their parents' needs; (b) that the schools provide from their own resources any sums needed above the maximum grants specified to pay the fees for any pupil they admit who may need further assistance; and (c) that the schools devise or accept tests of suitability for entry with enough options to enable children who have had different types of early education to show ability to profit by the education given in the schools.

\section{Scientific Men in Government Service}

Atrhough the article "Science and Government" by Dr. H. G. Moulton, president of the Brookings Institution (published in Science of December 11, 1942, which has just been received), is mainly concerned with relations between scientific workers and the Government of the United States, it is of some interest with regard to current discussions in Great Britain on the place of science in government. Dr. Moulton covers a wide field, including scientific research into the machinery of government as well as the conduct of scientific research by government and the use of scientifically trained men by government, and he suggests that the surest means of resolving the prevailing confusion of our time and of finding solutions to the baffling problems now confronting civilization lies in a re-integration of know. ledge through the systematic study of the various fields of science conceived as a whole. This is the primary function of the university, but the failure of the U.S. Government to make more effective use of science in the determination of policy is attributed to shortcomings in the organization of the American system of government and politics. Dr. Moulton points out that while the scientific men in government departments may assemble the data required with true scientific objectivity, they are usually debarred from interpreting the data or formulating conclusions to be drawn therefrom. There is no easy road to efficiency in government. Scientific men, business men and the general public must take an active and continuous interest in government, keeping themselves informed on the issues involved and electing honest, public-spirited and able servants. Public office-holding must be made a high calling, a worthy and rewarding career for anyone, and representatives must be encouraged to think in terms of the national welfare as a whole, rather than in terms of sectional or local interests.

\section{Sugar Research Foundation}

Dr. RoBert C. HocketT, associate professor of organic chemistry at the Massachusetts Institute of Technology, has been appointed scientific director of the Sugar Research Foundation. Following his graduation from Ohio State University, Dr. Hockett served there as graduate assistant in analytical chemistry. As a fellow of the National Research Council, he went to the National Institute of Health, United States Public Health Service, where he worked with Dr. C. S. Hudson. Dr. Hockett later became associate technologist of the Institute of Health and served in that position for several years. Since 1935, Dr. Hockett has been at the Massachusetts Institute of Technology, where he has developed a research programme on the chemistry of carbohydrates. Mr. Joseph F. Abbott, president of the Sugar Research Foundation, said that this appointment is the first step in a new scientific programme to extend know- ledge of the role of sugar and other carbohydrates in the human body and also of the chemical trans. formations to which sugars can be subjected. It is anticipated that such chemical studies, both fundamental and applied, will eventually indicate new industrial uses of sugar and its derivatives. Dr. Hockett has been granted five years leave of absence from the Massachusetts Institute of Technology to carry on his new work with the Foundation.

Mr. Abbott pointed out that the aims of the Sugar Research Foundation, which is a non-profit organization with offices at 99 Wall Street, New York 5, N.Y., and was formed last June, include the promotion of research and scientific studies at universities and other research institutions on the uses of sugar, and the dissemination of accurate information concerning sugar. It is supported by cane sugar refiners and beet sugar processors, as well as raw sugar producers of Hawaii, Louisiana and Puerto Rico. It is believed that research on the proper balance between carbohydrates and other food elements in the diet will do much to aid the public in utilizing intelligently lowcost energy foods, such as sugar. This will te of obvious importance during the present period of worldwide food shortages, and for some time after the cessation of hostilities, when populations will have to be fed on diets containing a high proportion of sugars and other carbohydrates.

\section{Development Advisor for West Africa}

The Secretary of State for the Colonies has appointed Mr. N. F. Hall, director of the National Institute for Economic and Social Research, to be development advisor for West Africa. He will be on the staff of the Resident Minister and will act in close consultation with the Governments of Nigeria, the Gold Coast, Sierra Leone and the Gambia, which have been working for some time on plans for postwar development. Mr. Hall has been on leave of absence from the National Institute since 1938 for war duties, and has served as joint-director of the Ministry of Economic Warfare; and more recently has been in charge of economic warfare work at the British Embassy, Washington, where he held the rank of Minister in the Diplomatic Service.

Mr. Maxwell Fry has been appointed townplanning advisor to the West African Governments; he will assist in the preparation of schemes for the largescale housing and town-planning which is contemplated by these Governments.

\section{Welsh Secretary of the Ministry of Agriculture}

Mr. J. Morgan Jones, registrar of the University College of Wales, Aberystwyth, has been appointed Welsh Secretary of the Ministry of Agriculture in succession to Dr. C. Bryner Jones as from March 31, 1944. Mr. Morgan Jones is the son of a Montgomeryshire farmer, and a former student of the University College of Wales, Aberystwyth. In 1924 he joined the staff of the newly established Advisory Department in Agricultural Economics of the College and remained as a member of Prof. A. W. Ashby's staff until 1930. In that year he was appointed to the Markets Division of the Ministry of Agriculture. He returned to Aberystwyth at the end of 1935 to become registrar at his old College. During the War he has been closely connected with the food production campaign in Wales in the capacity of Minister's liaison orticer for the counties of Cardigan, Pembroke, Carmarthen, Brecon and Radnor, and more recently 